\title{
Studi Potensi Talas Liar sebagai Sumber Bioetanol dan Implementasinya pada Pembelajaran Biologi
}

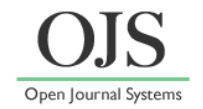

\author{
Herlina $^{1,2}$, Aceng Ruyani ${ }^{2}$, Zamzaili ${ }^{3}$, Budiyanto ${ }^{4}$ \\ ${ }^{1}$ SMAN 5 Kota Bengkulu, Provinsi Bengkulu \\ ${ }^{2}$ Program Pascasarjana Pendidikan IPA FKIP Universitas Bengkulu \\ ${ }^{3}$ Program Pascasarjana Pendidikan Matematika FKIP Universitas Bengkulu \\ ${ }^{4}$ Program Studi Teknologi Ilmu Pertanian Fakultas Pertanian Universitas Bengkulu \\ *Email: herlinabengkulu5@gmail.com
}

DOI: https://doi.org/10.33369/pendipa.v3i1.6922

\begin{abstract}
[Study of Potential of Wild Taro as a Bioethanol Source and Its Implementation in Biological Learning]. This research aims to (1) Determine the carbohydrate content in three types of wild taro. (2) Assessing the effect of different types of yeast on ethanol produced. (3) Assessing the effect of fresh and dried taro tubers on ethanol produced. (4) To find out the difference in learning outcomes of students who use research-based LKS and those who do not use research-based LKS. Bioethanol is obtained through fermentation using yeast. The method used is direct observation and testing of the bioethanol produced. The carbohydrate content of taro kembaang (Colocasia esculenta) in wet conditions is $23.04 \%$ and in dry conditions $78.433 \%$. For kemumu forest (Alocasia macrorrhiza) in wet conditions $20.08 \%$ and in dry conditions 79,725 . For black taro (Xantomonas nigrum) $23.20 \%$ in wet conditions and in dry conditions $72.622 \%$. Traditional yeast produces more ethanol than packaging yeast (Fermipan). More ethanol is produced in taro in dry conditions, namely kembaang taro (Colocasia esculenta) $2.30 \%$, kemumu taro forest (Alocasia macrorrhiza) $2.64 \%$ and black taro (Xantomonas nigrum) 2.23\%. Based on the fresh dried taro tuber, dried taro tubers produce more ethanol. LKS which is a learning resource is used to determine whether there is a difference between the experimental class and the control class using the $T$ test. There are significant differences in learning outcomes between the experimental classes using research-based LKS and the control class that does not use research-based LKS which is characterized by the T test test where th> tk, th = 18.3138 and $t k=2.0085$. So that the experimental class learning outcomes are better than the control class.
\end{abstract}

Keywords: Potential; wild taro; bioethanol; learning process.

(Received November 6, 2018; Accepted February 9, 2019; Published February 26, 2019)

\begin{abstract}
ABSTRAK
Penelitan ini bertujuan untuk (1) menentukan kandungan karbohidrat pada tiga jenis talas liar. (2) Mengkaji pengaruh perbedaan jenis ragi terhadap etanol yang dihasilkan. (3) Mengkaji pengaruh segar dan keringnya umbi talas terhadap etanol yang dihasilkan. (4) Untuk mengetahui perbedaan hasil belajar siswa yang menggunakan LKS berbasis riset dan yang tidak menggunakan LKS berbasis riset. Bioetanol didapatkan melalui fermentasi menggunakan ragi.Kandungan karbohidrat talas kembaang (Colocasia esculenta) pada kondisi basah $23.04 \%$ dan pada kondisi kering $78.433 \%$. Untuk talas kemumu hutan (Alocasia macrorrhiza) pada kondisi basah 20.08\% dan pada kondisi kering 79.725 . Untuk talas hitam (Xantomonas nigrum) $23.20 \%$ pada kondisi basah dan pada kondisi kering $72.622 \%$. Ragi tradisional lebih banyak menghasilkan etanol dari pada ragi kemasan (Fermipan). Etanol lebih banyak dihasilkan pada talas dalam kondisi kering yaitu talas kembaang (Colocasia esculenta) $2.30 \%$, talas kemumu hutan (Alocasia macrorrhiza) $2.64 \%$ dan talas hitam (Xantomonas nigrum) $2.23 \%$. Berdasarkan segar keringnya umbi talas, umbi talas kering lebih banyak menghasilkan etanol. LKS yang merupakan sumber belajar digunakan untuk mengetahui ada tidaknya perbedaan antara kelas eksperimen dan kelas kontrol dengan menggunakan uji T. Terdapat perbedaan hasil belajar yang signifikan antara kelas eksperimen yang menggunakan LKS berbasis riset dan kelas
\end{abstract}


kontrol yang tidak menggunakan LKS berbasis riset yang ditandai dengan uji $\mathrm{T}$ tes dimana th>tk, th $=$ 18.3138 dan tk $=2.0085$. Sehingga hasil belajar kelas eksperimen lebih baik dari pada kelas kontrol.

Kata kunci: Potensi; talas liar; bioetanol; pembelajaran.

\section{PENDAHULUAN}

Peningkatan jumlah penduduk yang cukup tinggi yang diiringi dengan kemajuan teknologi menyebabkan penggunaan bahan bakar fosil juga meningkat. Bahan bakar minyak merupakan kebutuhan vital bagi manusia. Tingginya harga BBM (Bahan Bakar Minyak) membuat rakyat semakin terjepit dan jumlahnya semakin berkurang. Hasil pembakaran BBM tidak ramah lingkungan, berakibat buruk terhadap kesehatan manusia.

Konsumsi BBM di Indonesia setiap tahun meningkat. Khusus premium dari 17 miliar liter kebutuhan pertahun, 30\% diantaranya impor (Trubus, 2008). Berdasarkan data PT Pertamina, konsumsi premium tahun 2009 sebesar 20,44 juta kilo liter dan tahun 2010 sebesar 22, 73 juta kilo liter. Subsidi BBM akan membengkak dan angka 40 juta kilo liter akan terlampaui di tahun 2012 (Basri, 2011). Mengingat kenaikan yang signifikan setiap tahun sebaiknya kita dapat mengurangi ketergantungan terhadap bahan bakar fosil dan dapat beralih ke Bahan Bakar Nabati. Salah satu Bahan Bakar Nabati adalah penggunaan bioetanol sebagai campuran pada premium. Bioetanol dapat diperoleh dari berbagai bahan, seperti pati, gula dan selulosa.

Tanaman talas merupakan salah satu plasma nutfah yang pemanfaatannya belum maksimal di Bengkulu. Talas mengandung pati yang dapat dimanfaatkan sebagai sumber bioetanol. Talas yang digunakan adalah talas liar yang tidak digunakan sebagai bahan pangan oleh masyarakat. Untuk pertumbuhannya tanaman ini tidak terlalu membutuhkan perawatan khusus. Tanaman ini banyak tumbuh liar di halaman atau pada lahan-lahan yang tidak digunakan.

Permasalahan BBM dengan fenomena seringnya terjadi kelangkaan BBM dapat dijadikan sumber belajar bagi siswa, dengan melibatkan siswa dalam mengidentifikasi masalah dan memecahkan masalah dalam kehidupan sehari-hari. Pembelajaran ini menggunakan pendekatan inkuiri dengan metode eksperimen dan menggunakan LKS berbasis riset.Pembelajaran berbasis riset digunakan untuk meningkatkan ketrampilan proses ilmiah karna siswa dilibatkan dalam pemecahan masalah melalui kegiatan eksperimen.Kegiatan eksperimen memerlukan LKS sebagai panduan Pratikum. Pembelajaran IPA merupakan proses untuk menanamkan dan mengembangkan aspek kognitif, afektif dan psikomotorik (Rustaman, 1997).

Bioetanol adalah etanol yang dibuat dari tumbuhan. Etanol dibuat dari biomassa yang mengandung pati, gula dan selulosa. Bioetanol merupakan bahan yang diperoleh dari proses Biologi [enzimatik dan fermentasi] (Prihandana, dkk 2007). Bioetanol diperoleh dari hasil fermentasi bahan yang mengandung gula, baik yang berupa glukosa, sukrosa maupun fruktosa oleh ragi(yeast) terutama Saccharomyces cerevisiae atau bakteri Zymomonas mobilis (Hambali, dkk 2007). Pada proses ini gula akan dikonversi menjadi etanol dan karbondioksida. Secara umum produksi bioetanol mencakupi tiga proses, yaitu persiapan bahan baku, fermentasi dan destilasi. Pada tahapan persiapan bahan baku berupa padatan dikenai pengecilan ukuran dan pemasakan bahan. Pada tahapan fermentasi dikenai ragi, tahapan destilasi merupakan tahap pemurnian. Destilasi dilakukan pada suhu di atas titik didih etanol murni yaitu $78-100^{\circ} \mathrm{C}$. Produk yang dihasilkan memiliki kemurnian hingga 96\%. Sebelum memasuki tahapan pemurnian dilakukan pemisahan antara etanol dan sludge yang dihasilkan.

Bioetanol untuk bahan bakar harus berkadar 99,5 \% (Trubus, 2008) sedangkan bioetanol hasil penyulingan masih berkadar $90 \%$, untuk masin belum bisa menyala karena kandungan airnya masih cukup tinggi. Bioetanol berkadar kemurnian 95\% masih layak dimamfaatkan sebagai bahan bakar motor tetapi sebaiknya ditambahkan zat anti korosif pada tangki bahan bakar. Penggunaan bioetanol sebagai bahan bakar dengan alkohol berkadar 99,5\%. Dalam aplikasinya bioetanol dipakai sebagai bahan aditif pada bensin yang dikenal dengan nama dagang gasohol dengan perbandingan $9: 1$. Penggunaan 100\% membutuhkan modifikasi mesin. Penggunaan gasohol merupakan salah satu upaya penghematan energi.

Salah satu jenis khamir yang berperan dalam fermentasi adalah Saccharomyces cerevisiae (Nurhidayat, 2006). Fermentasi adalah proses terjadinya dekomposisi gula 
menjadi alkohol dan karbondioksida (Wheeler, 1993). Fermentasi dilakukan pada kisaran suhu 27-32 ${ }^{0} \mathrm{C}$ (Hambali, dkk 2007). Pada tahap ini akan dihasilkan gas $\mathrm{CO} 2$ sebagai by product dan sludge sebagai limbahnya. Faktor-faktor yang mempengaruhi pertumbuhan ragi adalah temperatur, air, $\mathrm{pH}$ dan $\mathrm{pO}$, substrat (gula), tekanan osmosis, bahan-bahan penghambat dan pemicu fermentasi. Keperluan oksigen bagi ragi terjadi secara absolut (Walker, 1998)

Bahan bakar nabati memiliki kelebihan dibandingkan bahan bakar fosil yaitu dapat dibentuk hanya dalam kurun waktu yang tidak terlalu lama khususnya untuk pengolahan bahan bakar jenis etanol (Abidin, 2009). Talas merupakan bahan yang mengandung karbohidrat sekitar $13 \%$ hingga $29 \%$ sehingga talas dapat digunakan sebagai sumber bioetanol. Tanaman talas termasuk famili Araceae (Steenis, 2006). Famili Araceae merupakan herba atau perdu tidak berambut, menahun, kerap kali dengan umbi atau akar rimpang. Talas yang termasuk genus Colocasia memiliki umbi yang besar. Umbi talas banyak ragamnya baik yang menyangkut bentuk, ukuran, sifat daging, warna daging dan rasanya. Berat umbi talas berkisar antara 0,25-6 kg, tergantung jenisnya, kesuburan tanah, masa panen dan cara pembudidayaannya.

Peneliti melakukan penelitian untuk menentukan kandungan karbohidrat pada tiga jenis talas liar dan etanol yang dihasilkan, mengkaji pengaruh perbedaan jenis ragi terhadap etanol yang dihasilkan pada talas liar, mengkaji pengaruh segar keringnya umbi talas terhadap etanol yang dihasilkan dan mengetahui perbedaan hasil belajar siswa yang di ajar dengan bahan ajar menggunakan LKS dengan yang tidak menggunakan LKS

\section{METODE PENELITIAN}

Penelitian dilakukan dalam beberapa tahapan. Persiapan bahan baku di ambil dari habitat talas di Kecamatan Selebar. Persiapan bahan segar dan bahan kering di lakukan pada bulan Januari 2011 tempat penelitian di lakukan di Laboratorium TIP Fakultas Pertanian UNIB.Fermentasi dilakukan pada bulan Februari sampai Maret 2011.Fermentasi dilakukan di Laboratorium SMAN 5 BKL, Destilasi dilukukan di pada bulan Maret 2011 di Kebun Biologi UNIB

\section{Variabel penelitian sains}

Umbi talas segar, Umbi talas basah, Ragi tradisional, Ragi fermipan

\section{Variabel Penelitian Pendidikan}

Pembelajaran dengan menggunakan LKS berbasis riset dan yang tidak menggunakan LKS berbasis riset hasil belajar siswa

\section{Desain Penelitian Pendidikan}

Metode yang digunakan dalam penelitian ini adalah metode penelitian eksperimen dengan bentuk True eksperiment Design dengan post only control. Penelitian dilakukan pada dua kelas yang berbeda. Kelas pertama dilakukan pembelajaran dengan menggunakan LKS berbasis riset sebagai kelas eksperimen dan kelas kedua sebagai kelas kontrol tidak menggunakan LKS berbasis riset tetapi hanya menggunakan literatur.

\section{Teknik pengumpulan data}

Dalam melakukan penelitian ini penulis melakukan observasi dan pengujian langsung terhadap proses pembentukan etanol melalui tahapan persiapan bahan baku, fermentasi dan destilasi pada ketiga jenis talas liar. Dalam penelitian ini digunakan 3 jenis talas liar, 2 jenis ragi yang masing-masing dilakukan 3 kali ulangan sehingga keseluruhan terdapat 36 kali percobaan. Siswa dilibatkan dalam kegiatan fermentasi dan destilasi secara berkelompok. Untuk membantu pengumpulan data dan pengamatan, penulis menggunakan kamera digital.

Data hasil pembelajaran dikumpulkan dengan menggunakan tes pilihan ganda. Untuk memperoleh tes yang dapat dipercaya (reliabel) dilakukan uji panelis (ahli) terhadap tes tersebut dengan kriteria penilaian : $5=$ sangat baik, $4=$ baik, $3=$ cukup, $2=$ kurang, $1=$ sangat kurang.

\section{HASIL DAN PEMBAHASAN}

\section{Kandungan karbohidrat pada tiga jenis talas liar}

Tumbuhan talas merupakan tanaman herba atau perdu tidak berambut, tumbuhan menahun, berumbi atau akar rimpang. Tanaman ini mengandung karbohidrat dengan kadar yang berbeda-beda. 


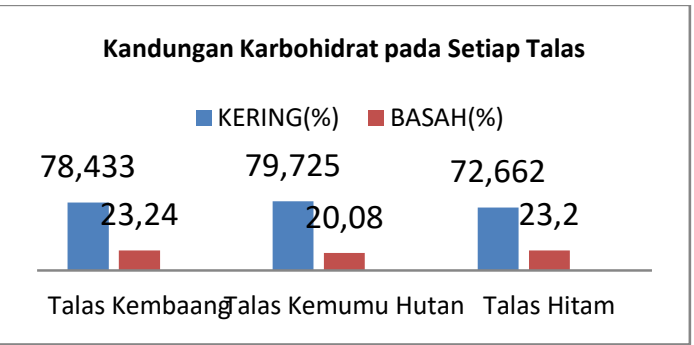

Gambar 1. Grafik Kandungan Karbohidrat pada Setiap Talas

Grafik pada Gambar 1 menunjukkan kandungan karbohidrat pada talas kering lebih tinggi dari pada talas basah pada ketiga jenis talas. Penggunaan ragi tradisional dan ragi kemasan terhadap etanol yang dihasilkan, menghasilkan etanol bila dibanding dengan ragi kemasan. Penggunaan kedua ragi tersebut dapat dilihat pada gambar dibawah ini :

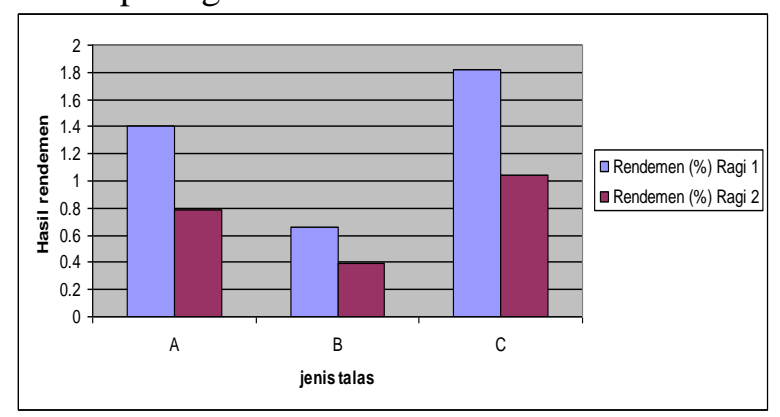

Gambar 2. Presentase rendemen pada talas basah

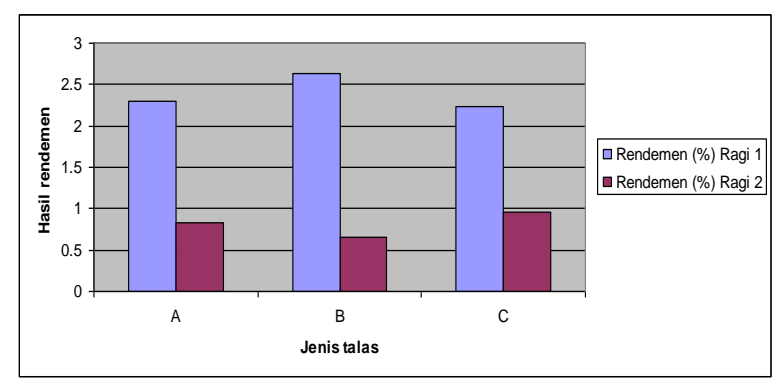

Gambar 3. Presentase rendemen pada talas kering

Gambar 2 dan 3 menunjukkan pengunaan ragi tradisional lebih banyak menghasilkan etanol pada kondisi kering. Pada kondisi kering karbohidrat yang dihasilkan lebih banyak sehingga kemampuan Saccharomyces cerevisiae untuk mengubah karbohidrat menjadi alkohol dan karbondioksida juga lebih tinggi. Salah satu faktor yang mempengaruhi fermentasi adalah kandungan monosakarida (Abidin, 2009). Kandungan monosakarida yang dihasilkan pada talas kering menyebabkan etanol yang dihasilkan juga lebih tinggi. Kondisi ini dapat dimanfaatkan jika terjadi kelebihan panen.

Ragi tradisional bekerja pda $\mathrm{pH} 5$ lebih asam dari pada ragi kemasan. Mikroorganisme yang bekerja selama fermentasi juga lebih banyak. Hal ini sesuai dengan penelitian Sadimo M, dkk (2016) kadar asam berpengaruh terhadap besarnya kadar gula yang dihasilkan. Bukan hanya Saccharomyces cerevisiae saja tetapi juga dari kelompok kapang dan bakteri. (Andarwulan, N. 2011) Kerjasama antar mikroorganisme yang lebih banyak menghasilkan etanol yang lebih banyak pula. Ragi Fermipan hanya terdiri dari Saccharomyces cerevisiae saja. Pengaruh segar keringnya umbi talas terhadap
etanol yang dihasilkan

Umbi talas kering lebih banyak menghasilkan etanol dari pada talas dalam kondisi basah. Hal ini disebabkan kadar air banyak yang menguap sehingga ikatan kimia antar molekul lebih padat.Hasil penelitian tersebut sesuai dengan penelitian Asgar,dkk (2010) Pengeringan berguna untuk mengatasi kelebihan panen.

Dari ketiga jenis talas liar, talas kemumu hutan (Alocasia macrorrhyza) menghasilkan presentase rendemen yang maksimal, karena rata-rata etanol yang dihasilkan setara dengan uji karbohidrat awal. Lingkungan tempat tumbuh berpengaruh terhadap karakteristik talas.

Perbedaan hasil belajar siswa yang menggunakan pembelajaran dengan LKS berbasis riset dan yang tidak menggunakan LKS berbasis riset.

Adanya perbedaan hasil post tes antara kelompok eksperimen dengan kelompok kontrol dapat ditunjukkan pada table dibawah ini

Tabel 1. Hasil Uji Hipotesis menggunakan T-tes

\begin{tabular}{|l|l|l|l|}
\hline Kelompok & $\mathbf{N}$ & $\overline{\mathbf{X}}=$ mean & $\mathbf{S}^{2}=$ varian \\
\hline $\begin{array}{l}\text { Kelompok } \\
\text { Eksperimen } \\
(\text { Ye })\end{array}$ & 26 & 94.6154 & 21,6862 \\
\hline $\begin{array}{l}\text { Kelompok } \\
\text { Kontrol } \\
(\text { Yk) }\end{array}$ & 26 & 69.0769 & 28,8738 \\
\hline
\end{tabular}

Tabel 1 menunjukkan bahwa rata-rata nilai pos test kelompok eksperimen lebih tinggi dari pada kelompok kontrol. Berdasarkan hasil uji T didapatkan Hasil $t_{h}=18,3138$. Dari tabel $t$, harga kritik $\mathrm{t}$ utk $\mathrm{db}=50, \mathrm{a}=0,05$ adalah Nilai $\mathrm{tk}=$ 
2,0085. Karena $t_{h}>t_{k}$, maka ada perbedaan atau terdapat perbedaan hasil belajar kelas eksperimen (Ye) dan kelas kontrol (Yk). Karena rata-rata kelas eksperimen lebih tinggi dari ratarata kelas kontrol maka hasil belajar kelas eksperimen lebih baik dari kelas kontrol

Hasil penelitian ini sesuai dengan penelitian Usmeldi (2015) yang menunjukkan bahwa hasil analisis aktivitas siswa yang menggunakan LKS berbasis riset sangat baik. Hasil penelitian Slameto (2015) juga menunjukkan bahwa pembelajaran berbasis riset mampu meningkatkan hasil belajar siswa dari $8 \%$ hingga $21 \%$. Model pembelajaran ini digunakan untuk membantu siswa melatih kemampuan berpikir, memecahkan masalah, dan keterampilan intelektual dengan mengarahkan siswa untuk menemukan konsep dengan adanya bimbingan dari guru. LKS berbasis riset melibatkan siswa dalam pemecahan masalah, prosedur percobaan dalam LKS sesuai dengan metode inquiri terbimbing sehingga siswa dapat menemukan konsep dan berpikir kritis.Metode ini sangat sesuai dengan paradigma pembelajaran yang diinginkan pada abad pengetahuan yaitu pembelajaran yang berorientasi pada proyek, masalah, penyelidikan, penemuan dan penciptaan .

\section{KESIMPULAN}

Talas kembaang (Colocasia esculenta), Talas kemumu hutan (Alocasia macrorrhiza), Talas kemumu hutan ( Xantomonas nigrum) mengandung karbohidrat dengan presentase yang berbeda. Masing-masing talas tersebut dapat dijadikan substrat untuk menghasilkan bioetanol. Dalam proses fermentasi penggunaan ragi tradisional menghasilkan presentase rendemen yang lebih tinggi dari pada ragi Fermipan. Talas pada kondisi kering menghasilkan etanol yang lebih banyak dari pada kondisi basah. Sehingga hal ini dapat dimanfaatkan jika terjadi kelebihan panen. Pembelajaran dengan menggunakan LKS berbasis riset dapat meningkatkan pencapaian hasil belajar siswa.

\section{REFERENSI}

Abidin, R. (2009). Membuat bensin dari ubi. Jakarta : Bentara cipta prima
Andarwulan, N. Semua ragi. (2011). Jurusan Teknologi pangan dan gizi Fakultas Teknologi Pertanian. IPB.Bogor

Asgar, A. Kartasih, A. Supriadi, A.Trysdiani, H. (2010). Pengaruh penyimpanan, suhu dan lama pengeringan kentang terhadap kualitas keripik kentang putih.http://jurnal pdii lipi.go.id/admin/jurnal. Balai penelitian tanaman sayuran Pusat penelitian dan pengembangan Holtikultura

Basri, M.H. (2011). Pesan pesimistis dari pemerintah. Kompas.

Halaman 15.

Hambali, E. Mudjalifah, S. Tambunan, H. A. Pattiwiri, W.A. Hendroko, R. (2007). Teknologi Bioenergi. Jakarta: Agro media

Hidayat, N. Padaga C, M. Suhartini, S. (2006). Mikrobiologi Industri. Jogjakarta : ANDI. http://snf-unj.ac.id/kumpulanprosiding/snf2015/

Prihandana, R. Noerwijan, K. Adinurani, P.G, Setyaningsih, D.Setiadi, S.Hendroko, R. (2007). Bioetanol ubi kayu bahan bakar masa depan. Jakarta : Agromedia.

Rustaman, N. Rustaman A. (1997). Pokok-pokok pengajaran Biologi kurikulum 1994. Jakarta : Depdikbud

Sadimo, M. Said, I. Mustopa, K. (2016). Pembuatan bioetanol dari pati umbi talas (Colocasia esculenta L schoot) melalui hidrolisis asam dan fermentasi. https://media.neliti.com/media/publication s/224204-pembuatan-bioetanol-dari-patiumbi-talas.pdf

Slameto. (2015). Pembelajaran berbasis riset mewujudkan pembelajaran yang inspiratif. https://www.researchgate.net/publication/ 315342555_PEMBELAJARAN_BERBA SIS_RISET_MEWUJUDKAN_PEMBEL AJARAN_YANG_INSPIRATIF

Steenis, V. (2006). Flora. Jakarta. Pradnya paramita

Trubus. (2008). Agustus. Langit biru berkat bioetanol. Halaman 51-61

Usmeldi. (2015). Pengembangan Lembar Kerja Siswa Dalam Pembelajaran Fisika Berbasis Riset di SMAN 1 Padang.

Volk, W.A. Wheeller, M.F. (1993). Mikrobiologi dasar. Jakarta : Erlangga

Walker,G.M. (1998). Yeast. Physiology and Bioteknologi. Universitas of abertay dundee Schotland 